\title{
EFFECTS OF PALM KERNEL BIOCHAR ON THE PHYSIOLOGICAL RESPONSES AND ROOT PROFILES OF SENDUDOK (MELASTOMA MALABATHRICUM L.) GROWN ON ACIDIC SOIL
}

\author{
RUSLI, L. S. ${ }^{1,2^{*}}-$ OSMAN, N. ${ }^{1 *}-$ ABDULlaH, R. ${ }^{1}-$ YAACOB, J. S. ${ }^{1,3}-$ SEOW, A. H. ${ }^{1}$ \\ ${ }^{1}$ Institute of Biological Sciences, Faculty of Science, Universiti Malaya, 50603 Kuala Lumpur, \\ Malaysia
}

${ }^{2}$ Faculty of Applied Sciences, Universiti Teknologi MARA Cawangan Negeri Sembilan, Kampus Kuala Pilah, Pekan Parit Tinggi, 72000 Kuala Pilah Negeri Sembilan Darul Khusus, Malaysia

${ }^{3}$ Centre for Research in Biotechnology for Agriculture (CEBAR), Universiti Malaya, 50603

Kuala Lumpur, Malaysia

(phone: +60-37-967-4360; fax: +60-37-967-4178)

*Corresponding authors

e-mail:normaniza@um.edu.my, lilis369@uitm.edu.my

(Received 23 $3^{\text {rd }}$ Nov 2020; accepted $14^{\text {th }}$ May 2021)

\begin{abstract}
Soil acidity is one of the key limitations that hinder plant development, especially on an acidic slope. Soil amendments such as ground magnesium limestone, compost and biochar are often utilized as a technique to restore soil fertility and promote plant growth. However, studies on the effect of biochar amelioration on plants grown on acidic soil are still lacking. Therefore, this research aims to investigate the contribution of biochar, either individually or in co-application with compost and ground magnesium limestone on the physiological responses and root profiles of Melastoma malabathricum grown on acidic soil. Results showed that the physiological attributes such as stomatal conductance, transpiration rate and relative chlorophyll content were observed to be highest in biochar which was $50.00 \%, 79.45 \%$ and $22.94 \%$ respectively. Application of biochar also resulted in the highest root length and root length density. Surprisingly, higher leaf development was found in the co-application of biochar and compost which enhanced the shoot growth. A strong positive correlation was observed between transpiration rate and stomatal conductance. In conclusion, based on the highest number of promising physiological and root profile parameters, we propose the application of biochar alone, to improve the physiological attributes and root establishment of M. malabathricum, in addition to alleviating the negative effects of soil acidification.
\end{abstract}

Keywords: soil amendment, herbaceous species, plant physiology, root profiling, soil acidity

\section{Introduction}

Soil acidification of slope induced by anthropogenic activities such as agricultural and mining is a great concern, threatening the natural ecosystem (Chen et al., 2013). Besides that, the high volume of precipitation received annually in Malaysia, at 2000$2500 \mathrm{~mm}$ hastens acidification of slope soils (Galvão et al., 2010; Aimee and Normaniza, 2014). Thus, the slope condition is known to be harsh and unconducive for plant growth, thereby making it difficult for plants to establish and survive on the acidic slope soil in Malaysia (Shamshuddin et al., 2011; Osman et al., 2014) rendering them to become erosion prone areas (Bezdicek et al., 2003).

The contribution of vegetation towards the enhancement of slope stability is garnering greater attention as it is eco-friendly while the well management of vegetation 
on slope enhances soil shear strength, mitigating erosion and decreasing the possibility of slope failure with the rise in plant biomass (Osman and Barakbah, 2011).

Unfortunately, the role of plants in maintaining the slope stability is severely influenced by the soil acidification (Dobermann and Fairhurst, 2000; Mullen et al., 2007). The soil fertility, biological activities, and plant productivity are negatively affected by the acidification of soil (Soriano, 2014). Additionally, Rahman et al. (2018) also revealed that aluminium (Al) toxicity inhibits plant growth and development in acidic soils (Rahman et al., 2018). Root growth is restricted, leading to impaired water and nutrient acquisition by the plants (Kochian et al., 2005; Dai et al., 2014; Delhaize and Ryan, 1995), which are then translated to producing low crop yields (Caires et al., 2008; Shamshuddin, 2006). Hence, the biodiversity, ecosystem functioning, and the balance of the ecosystem would also be affected by soil acidification (bin Wasli et al., 2009; Graham and Haynes, 2005; Hoegberg et al., 2006).

Many studies have revealed that biochar is able to enhance plant growth, with positive attributes observed in nutrient availability, nutrient uptake, and root growth (Masto et al., 2013; Lehmann and Joseph, 2015; Gunarathne et al., 2017). The rate of sediment loss is also decreased by applying biochar and hence alleviating the erosion (Jien and Wang, 2013). Apart from that, a stable form of carbon can be sequestered and stored to mitigate global warming and improve soil fertility to attain maximum crop production by amending the soil with biochar (Kong et al., 2019).

Melastoma malabathricum has been known to be a potential slope plant (Saifuddin et al., 2016) and Al hyperaccumulator (Watanabe et al., 2006; Maejima et al., 2017) that has the ability to tolerate harsh and acidic conditions (Aimee and Normaniza, 2014). The plant has M-type roots which enables them to grow extensively in various directions and is beneficial in controlling soil erosion by improving the mechanical and hydrological properties (Aimee and Normaniza, 2014; Saifuddin and Normaniza, 2016). Nonetheless, the growth rate and the size of the species grown on acidic slope is far lower than those grown on less acidic area (Chen et al., 2013; Van den Berg et al., 2011). Hence, the current study is aimed to investigate the effect of biochar on the plant growth, soil properties and root profile of $M$. malabathricum grown under acidic conditions. In addition, we address ameliorating issues of soil acidification, leading to greater vegetation coverage on slope.

\section{Materials and methods}

\section{Site description}

This study was carried out in a glasshouse located at Rimba Ilmu, Institute of Biological Sciences, Universiti Malaya, Kuala Lumpur, Malaysia ( $3^{\circ} 7$ ' 52.1076" N, $101^{\circ} 39^{\prime} 25.218$ " E) from August 2019 to February 2020. The atmospheric temperature under the glasshouse varied from $25-28^{\circ} \mathrm{C}$, while the relative humidity $(\mathrm{RH})$ and maximum photosynthetically active radiation (PAR) recorded was 65-90\% and $2000 \mu \mathrm{E} \mathrm{mol} \mathrm{m} \mathrm{m}^{-2}$ respectively.

\section{Experimental design and plant materials}

The seedlings of one-month old M. malabathricum, were obtained from the nursery at Sungai Buloh, Selangor, Malaysia. The initial height of the seedlings was $10 \mathrm{~cm}$ in average. The plants were grown in polybags with a dimension of $26 \mathrm{~cm} \times 20 \mathrm{~cm}$ and 
each of it was filled with $8164 \mathrm{~cm}^{3}$ of topsoil, and arranged in a Complete Randomized Design (CRD). The volume of soil adequately allows the optimal establishment of the root system within the duration of the study (Kawaletz et al., 2014). Throughout the experiment, the plants were watered once daily to maintain their turgidity and to prevent water stress. Five treatments including the control were studied in this experiment and each treatment comprised of six replications, resulted in a total number of 30 plants. Ground magnesium limestone and palm kernel biochar were applied into experimental soil: (1) control (denoted as Q); (2) palm kernel biochar applied at $10 \mathrm{t} \mathrm{ha}^{-1}$ (denoted as B); (3) combination of $5 \mathrm{t} \mathrm{ha}^{-1}$ palm kernel biochar and $5 \mathrm{t} \mathrm{ha}^{-1}$ ground magnesium limestone (denoted as BL); (4) combination of $5 \mathrm{t} \mathrm{ha}^{-1}$ palm kernel biochar and $5 \mathrm{t} \mathrm{ha}^{-1}$ food waste compost (denoted as BC); (5) combination of $10 \mathrm{t} \mathrm{ha}^{-1}$ palm kernel biochar, food waste compost and ground magnesium limestone (denoted as BCL). Biochar was sourced from Malaysian Palm Oil Board (MPOB, Malaysia) and compost was from UM ZWC (Universiti Malaya, Malaysia). The details of the physicochemical characteristics of the organic amendments are as described by Abdullah et al. (2020). The texture of the acidic soil was a sandy loam ( $7.12 \%$ clay; $39.83 \%$ sand; $53.04 \%$ silt), with an initial $\mathrm{pH}$ of 3.90 .

\section{Parameters measured}

The plants were monitored bimonthly, started from 14 days after planting and the data was collected accordingly throughout the six months.

\section{Soil pH}

Soil samples were taken twice to determine their $\mathrm{pH}$ values, representing the initial and final soil $\mathrm{pH}$. The soil was sampled and dried in the oven at $60{ }^{\circ} \mathrm{C}$ for $24 \mathrm{~h}$. The dried soil was then sieved through a $2.0 \mathrm{~mm}$ mesh. Calibration of the $\mathrm{pH}$ meter (PB-10, Sartorius $\mathrm{GmbH}$, Germany) was first carried out by using the buffer solutions of $\mathrm{pH} 7$ followed by $\mathrm{pH} 4$ before determining the $\mathrm{pH}$ values of the soil samples. The soil $\mathrm{pH}$ was measured from the supernatant of the mixed sample and distilled water with a volume ratio of soil:solution at 1:2.5 (Gentili et al., 2018). The average $\mathrm{pH}$ reading was taken from the pooled sample of six biological replications for each treatment.

\section{Electrical conductivity (EC)}

The electrical conductivity of the soil samples was measured twice to obtain the initial and final stage reading by using an electrical conductivity meter. The soil was sampled and dried in the oven at $60{ }^{\circ} \mathrm{C}$ for $24 \mathrm{~h}$. The dried soil was then sieved through a $2.0 \mathrm{~mm}$ mesh. Calibration with a standard solution of known electrical conductivity was first carried out, followed by the measurement of soil electrical conductivity with a volume ratio of soil:solution at 1:5, with the usage of distilled water. The soil samples of six biological replications for each treatment taken were pooled. Three replications of readings for electrical conductivity were determined and the average readings were calculated.

\section{Leaf area index (LAI)}

Leaf area index was determined at the initial, middle and final stages of the study by using a Ceptometer (AccuPAR LP-80 Decagon Devices, Inc, USA). The average 
reading per plant, above and below the plant were taken using a 1-m long bar, with 80 sensors divided into eight segments.

\section{Relative chlorophyll content}

A chlorophyll meter (SPAD-502, Minolta, Japan) was used to determine the relative chlorophyll content. The readings were taken monthly between 0930-1130 h, at the peak of photosynthesis process. Three replications of readings of relative chlorophyll were taken manually and the average was determined.

\section{Photosynthetic rate, stomatal conductance and transpiration rate}

A portable photosynthesis system (LiCor-6400; LiCor Inc., USA) was used to determine the photosynthetic rate, stomatal conductance and transpiration rate of the plants between $0930 \mathrm{~h}$ and $1130 \mathrm{~h}$, in which the peak of photosynthesis process of the species studied took place (Aimee and Normaniza, 2014). Fully expanded and matured leaves were chosen to determine the rate of photosynthesis. Three technical replications were logged and recorded automatically for each of the six biological replicates. Initial and final readings were taken throughout the study.

\section{Plant biomass}

The plants were harvested after six months of planting period. The leaves, stems and roots of the plants were separated and dried in the oven at $65^{\circ} \mathrm{C}$ for $48 \mathrm{~h}$ to obtain constant weights.

\section{Root profile studies}

Root measurement in different forms were carried out with the usage of an image system automated root scanner (WinRHIZO Pro v. 2008a, Regent Instruments Inc., Canada). The harvested roots were carefully separated from the soil and washed with tap water on 2.0-mm sieve. Prior to root scanning, the root samples were stored at $4{ }^{\circ} \mathrm{C}$. It was ensured that there were no water droplets on the roots before scanning was carried out. In addition to the root length, the diameter and volume of root were also determined. The diameter of a root system can be determined by dividing the projected area of the imaged root by its total length, root length can be determined by multiplying the number of pixels in a one-pixel thinned image by the pixel size, root volume can be determined using the root surface area and length, and root surface area can be determined by determining the root diameter and length (Piñuela et al., 2020). Three replications of readings for each data were determined to obtain the average readings.

\section{Statistical analysis}

The results obtained were analyzed by using the SPSS 25.0 statistical package program (SPSS Institute, USA). The statistical differences between and among the treatments were assessed with t-test and one-way analysis of variance (ANOVA), respectively. The Tukey test was carried out as a post hoc test to determine the differences between the treatments at 0.05 of probability level. Correlations among data were calculated using Pearson's correlation coefficient in bivariate correlations. 


\section{Results}

\section{Soil pH and electrical conductivity}

Overall results showed that the soil $\mathrm{pH}$ was significantly affected by the soil amendments. The co-application of biochar and ground magnesium limestone (BL) exhibited a highest significant increment of $\mathrm{pH}$, whereas control (Q) treatment recorded the lowest (Fig. 1a). The three combined amendments (BCL) also showed a significantly higher increment throughout the observation.

Similar to soil $\mathrm{pH}$, the electrical conductivity (EC) was also affected by the amendments. A significant highest increment of EC was displayed in the soil of combined amendments (BCL; Fig. 1b). In contrast to the $\mathrm{pH}$ performance, soil of BL treatment recorded the lowest increment of EC.
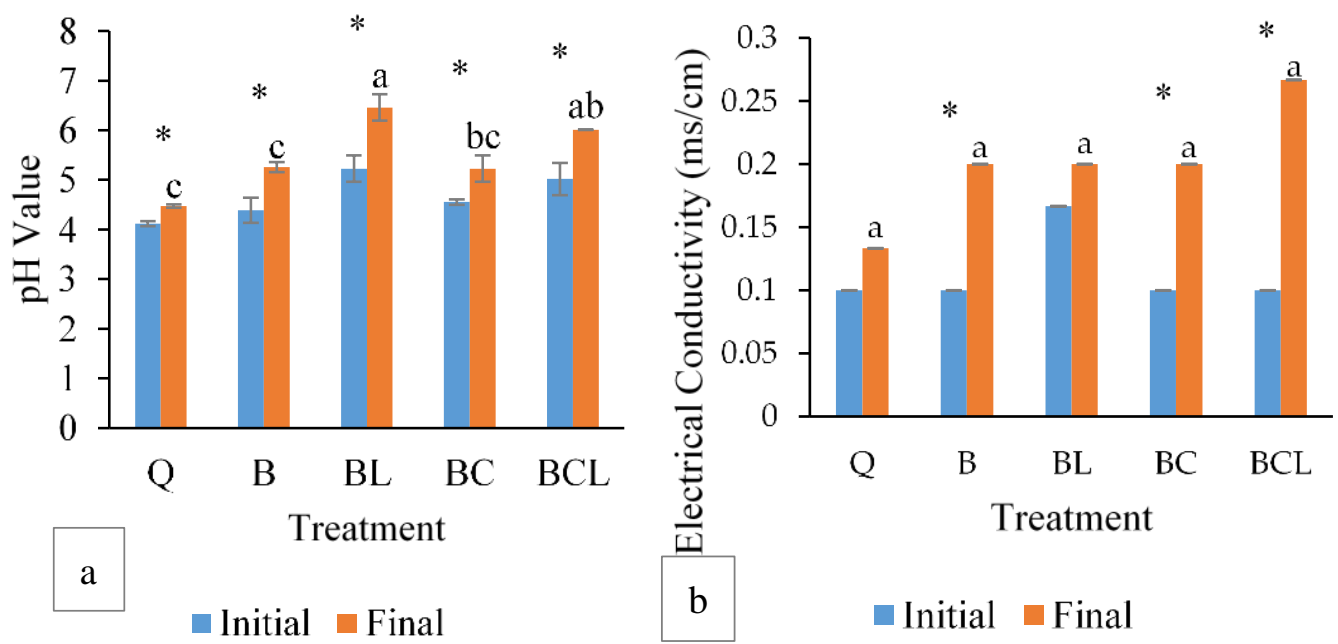

Figure 1. (a) Soil $p H$ and (b) soil electrical conductivity $(n=3)$. Vertical bars represent standard deviation. Asterisks represent significant difference at $p<0.05$ between initial and final planting. Different letters indicate a significant difference amongst the treatments during final planting at $p<0.05 ; Q=$ control, $B=$ biochar, $B L=$ biochar + ground magnesium limestone, $B C=$ biochar + compost,$B C L=$ biochar + compost + ground magnesium limestone

\section{Leaf area index and relative chlorophyll content}

An increasing trend was observed though there were no significant difference in the leaf area index (LAI) of $M$. malabathricum throughout the planting period in all treatments. The LAI of $M$. malabathricum grown in the soil treated by both biochar and compost (BC) achieved the highest increment, 238.50\%, whilst BCL exhibited the lowest increment at $99.00 \%$, throughout the planting period (Fig. 2). Specifically, plants grown in BC treatment had the highest increment, $144.92 \%$, between the initial and middle period of planting. For the middle to final planting period, biochar (B) alone gave the highest increment, $80.00 \%$. In all observations, the plants grown in the control (Q) soil exhibited the lowest increments.

The relative chlorophyll content of plants grown in all treatments decreased in general, though there were no statistically significant differences between them (Fig. 3). The relative chlorophyll content of plants applied with biochar (B) decreased at the lowest rate, which was about $10.46 \%$ throughout the six months of study. In contrast, the relative chlorophyll content of control (Q) plant decreased at the highest rate, 
$27.44 \%$ in the third month of study. At the end of observation, treatment B showed the highest relative chlorophyll content compared to other treatments.

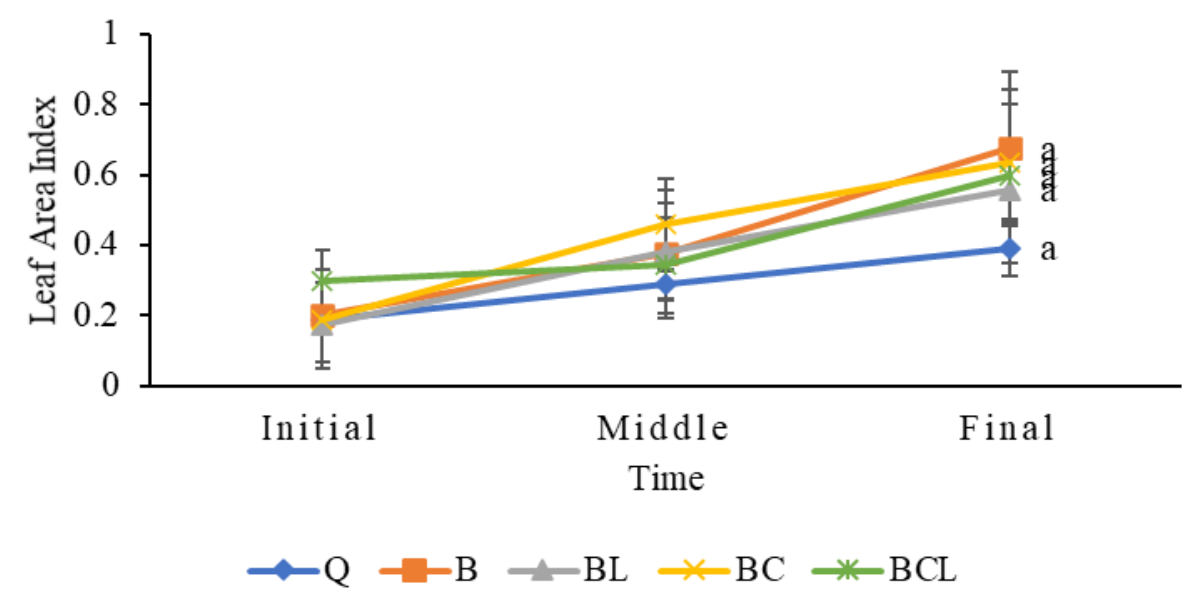

Figure 2. Leaf area index $(n=6)$. Vertical bars represent standard deviation. Different letters indicate a significant difference $(p<0.05)$ amongst treatments in final planting period; $Q=$ control, $B=$ biochar, $B L=$ biochar + ground magnesium limestone, $B C=$ biochar + compost, $B C L=$ biochar + compost + ground magnesium limestone

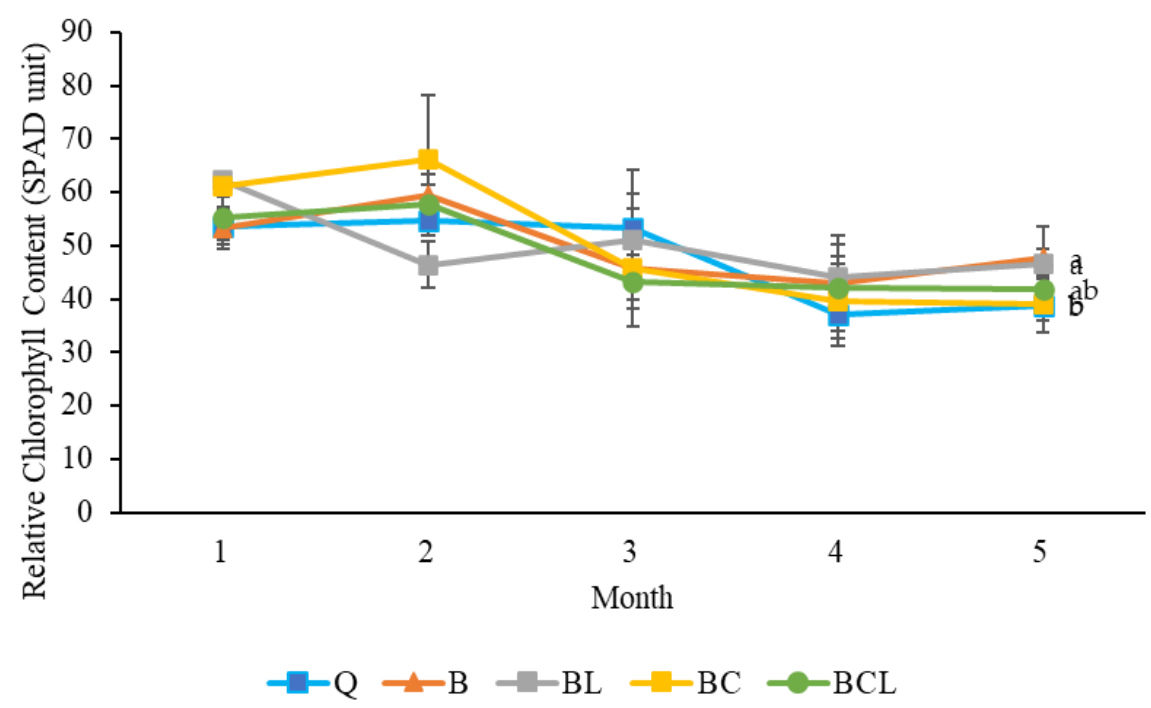

Figure 3. Relative chlorophyll content of M. malabathricum $(n=6)$. Vertical bars represent standard deviation. Different letters indicate a significant difference $(p<0.05)$ amongst treatments in month 5; $Q=$ control, $B=$ biochar, $B L=$ biochar + ground magnesium limestone, $B C=$ biochar + compost,$B C L=$ biochar + compost + ground magnesium limestone

\section{Physiological responses}

In general, all treatments resulted in adverse responses in physiological performance of M. malabathricum (Table 1). The photosynthetic rates of all the treatments showed decrement towards the end of the experiment. The photosynthetic rate of plants coapplied with three combined amendments (BCL) decreased at the highest rate, $65.70 \%$. In the final planting period, a significantly higher photosynthetic rate was witnessed in 
biochar and ground magnesium limestone (BL) treatment. Nevertheless, the photosynthetic rates of all treatments were significantly higher as compared to the control $(\mathrm{Q})$ at both planting periods.

Overall, a similar trend was observed for stomatal conductance and transpiration rate of the species studied. Significant differences were found between the initial and final planting periods for both stomatal conductance and transpiration rate. Biochar (B) treatment recorded the highest increments of stomatal conductance and transpiration rate at $50.00 \%$ and $79.45 \%$, respectively. Also, treatment $\mathrm{B}$ exhibited the highest stomatal conductance and transpiration rate in the final planting period.

Table 1. Physiological responses of $M$. malabathricum at the initial and final planting period

\begin{tabular}{c|c|c|c|c|c|c}
\hline \multirow{2}{*}{ Treatment } & \multicolumn{2}{|c|}{$\begin{array}{c}\text { Photosynthetic rate } \\
\left(\mu \mathbf{m o l ~ m}^{-\mathbf{2}} \mathbf{s}^{-\mathbf{1}}\right)\end{array}$} & $\begin{array}{c}\text { Stomatal conductance } \\
\left(\mathbf{m o l ~ m}^{-\mathbf{2}} \mathbf{~ s}^{-\mathbf{~}}\right)\end{array}$ & \multicolumn{2}{c}{$\begin{array}{c}\text { Transpiration rate } \\
\left(\mathbf{m m o l ~ m}^{-\mathbf{2}} \mathbf{s}^{-\mathbf{1}}\right)\end{array}$} \\
\cline { 2 - 7 } & Initial & Final & Initial & Final & Initial & Final \\
\hline Q & $5.62^{\mathrm{e}}$ & $4.18^{\mathrm{c}}$ & $0.03^{\mathrm{b}}$ & $0.01^{\mathrm{c}}$ & $0.84^{\mathrm{bc}}$ & $0.45^{\mathrm{a}}$ \\
B & $11.48^{\mathrm{d}}$ & $7.36^{\mathrm{b}}$ & $0.02^{\mathrm{b}}$ & $0.03^{\mathrm{a}}$ & $0.73^{\mathrm{c}}$ & $1.31^{\mathrm{a}}$ \\
BL & $13.37^{\mathrm{c}}$ & $10.12^{\mathrm{a}}$ & $0.02^{\mathrm{c}}$ & $0.02^{\mathrm{b}}$ & $0.52^{\mathrm{d}}$ & $0.91^{\mathrm{a}}$ \\
BC & $20.23^{\mathrm{a}}$ & $8.09^{\mathrm{b}}$ & $0.03^{\mathrm{a}}$ & $0.03^{\mathrm{b}}$ & $0.99^{\mathrm{ab}}$ & $1.08^{\mathrm{a}}$ \\
BCL & $18.25^{\mathrm{b}}$ & $6.26^{\mathrm{b}}$ & $0.03^{\mathrm{a}}$ & $0.01^{\mathrm{c}}$ & $1.07^{\mathrm{a}}$ & $0.54^{\mathrm{a}}$ \\
\hline
\end{tabular}

Significant difference amongst treatments were assessed using a one-way ANOVA accordingly at $\mathrm{p}<0.05$. Mean within each column followed by a different letter indicate a significant difference amongst the treatments $(\mathrm{p}<0.05) ; \mathrm{Q}=$ control, $\mathrm{B}=$ biochar, $\mathrm{BL}=$ biochar + ground magnesium limestone, $\mathrm{BC}=$ biochar + compost, $\mathrm{BCL}=$ biochar + compost + ground magnesium limestone

\section{Biomass}

Generally, no significant differences among treatments were observed in the leaf biomass. However, the stem and root biomass were much affected by the treatments. The co-application of biochar and compost (BC) exhibited the highest leaf biomass which was $1.32 \%$ higher than the control (Table 2). Moreover, biochar (B) treatment recorded the highest stem biomass which was $9.35 \%$ higher than the control. Biochar and ground magnesium limestone (BL) treatment displayed the highest root biomass which was $88.06 \%$ significantly higher than those in control.

Table 2. Effect of soil amendments on biomass of M. malabathricum

\begin{tabular}{c|c|c|c}
\hline \multirow{2}{*}{ Treatment } & \multicolumn{3}{|c}{ Biomass $(\mathbf{g})$} \\
\cline { 2 - 4 } & Leaf & Stem & Root \\
\hline Q & $10.62^{\mathrm{a}}$ & $8.56^{\mathrm{ab}}$ & $6.53^{\mathrm{cd}}$ \\
B & $9.49^{\mathrm{a}}$ & $9.36^{\mathrm{a}}$ & $5.24^{\mathrm{d}}$ \\
BL & $9.55^{\mathrm{a}}$ & $6.98^{\mathrm{bc}}$ & $12.28^{\mathrm{a}}$ \\
BC & $10.76^{\mathrm{a}}$ & $8.94^{\mathrm{a}}$ & $9.81^{\mathrm{ab}}$ \\
BCL & $6.34^{\mathrm{b}}$ & $6.39^{\mathrm{c}}$ & $8.61^{\mathrm{bc}}$ \\
\hline
\end{tabular}

Significant difference amongst treatments were assessed using a one-way ANOVA accordingly at $\mathrm{p}<0.05$. Mean within each column followed by a different letter indicates significant differences amongst the treatments; $\mathrm{Q}=$ control, $\mathrm{B}=$ biochar, $\mathrm{BL}=$ biochar + ground magnesium limestone, $\mathrm{BC}=$ biochar + compost, $\mathrm{BCL}=$ biochar + compost + ground magnesium limestone 


\section{Root profiles}

Overall, the root length and root length density displayed a similar trend of response towards the treatments. Meanwhile, the average diameter and root volume also exhibited a similar style of treatment response. Biochar (B) treatment displayed the highest root length and root length density which was $20.25 \%$ higher than control (Fig. 4a, b). The three combined amendments (BCL) had the lowest root diameter and root volume after six months of observation (Fig. $4 c, d$ ). All treatments resulted in a decrease in root volume when compared to the control (Fig. 5).
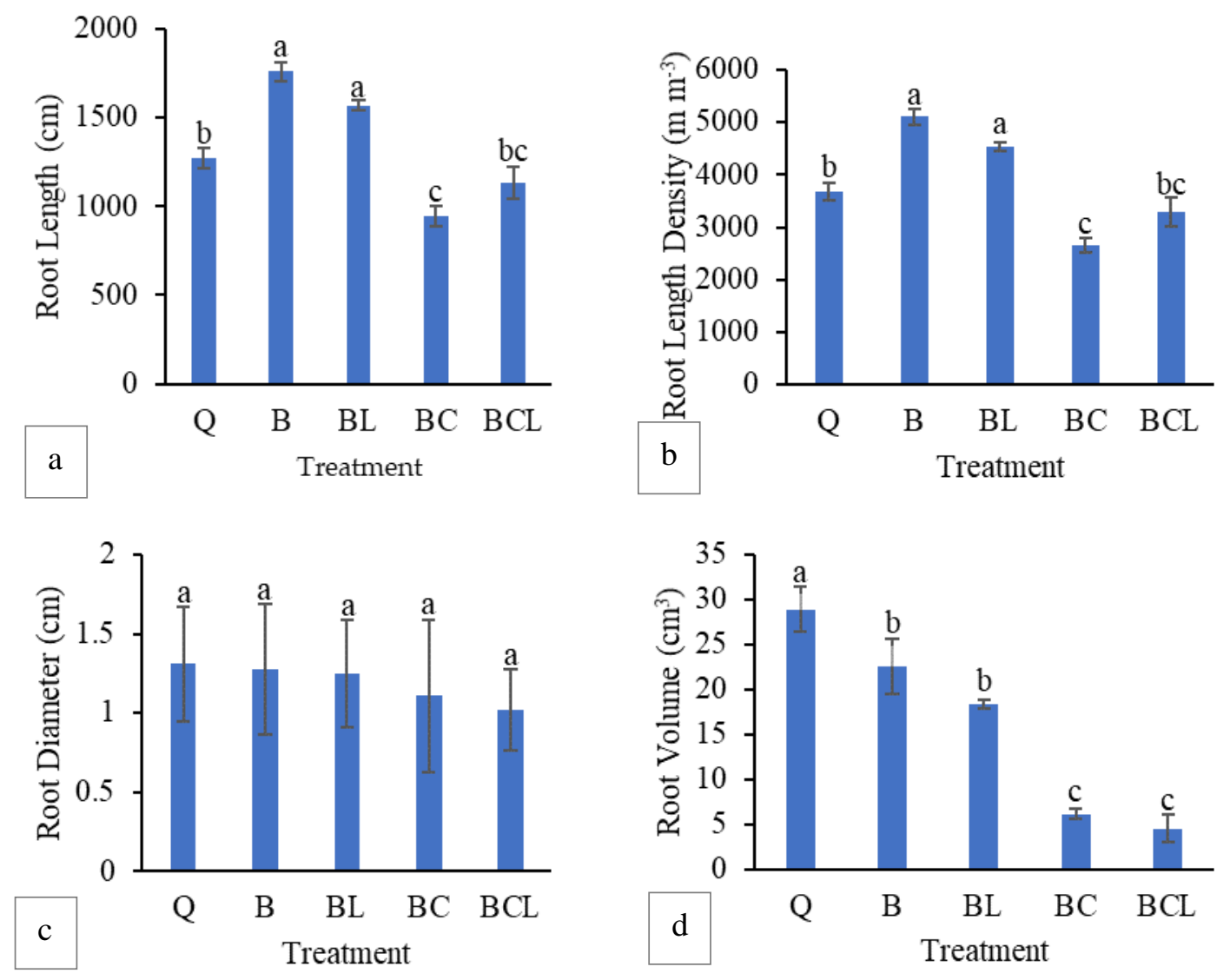

Figure 4. Effects of different amendments on (a) root length, (b) root length density, (c) root diameter and $(d)$ root volume of $M$. malabathricum $(n=6)$. Vertical bars indicate the standard deviation. Different letters indicate significant difference amongst treatments $(p<0.05)$; $Q=$ control, $B=$ biochar, $B L=$ biochar + ground magnesium limestone, $B C=$ biochar + compost,$B C L=$ biochar + compost + ground magnesium limestone

\section{Correlations amongst the parameters studied}

A Pearson's correlation analysis was carried out to determine the relationship between the parameters (Table 3). The leaf area index, relative chlorophyll content and rate of photosynthesis were directly related to the soil $\mathrm{pH}$. Analysis of results revealed a strong positive correlation between the soil $\mathrm{pH}$ and rate of photosynthesis $(\mathrm{r}=0.65)$ (significant at $\mathrm{P} \leq 0.01$ ). This indicated that the rate of photosynthesis would significantly increase with the increase of soil $\mathrm{pH}$. In contrast, negative correlations 
between soil $\mathrm{pH}$ with the stomatal conductance and transpiration rate were observed, with $\mathrm{r}$ value of -0.095 and -0.105 respectively. Moreover, soil $\mathrm{pH}$ also negatively correlated with root length $(r=-0.250)$, root length density $(r=-0.306)$, root diameter $(\mathrm{r}=-0.219)$ and root volume $(\mathrm{r}=-0.721)$.
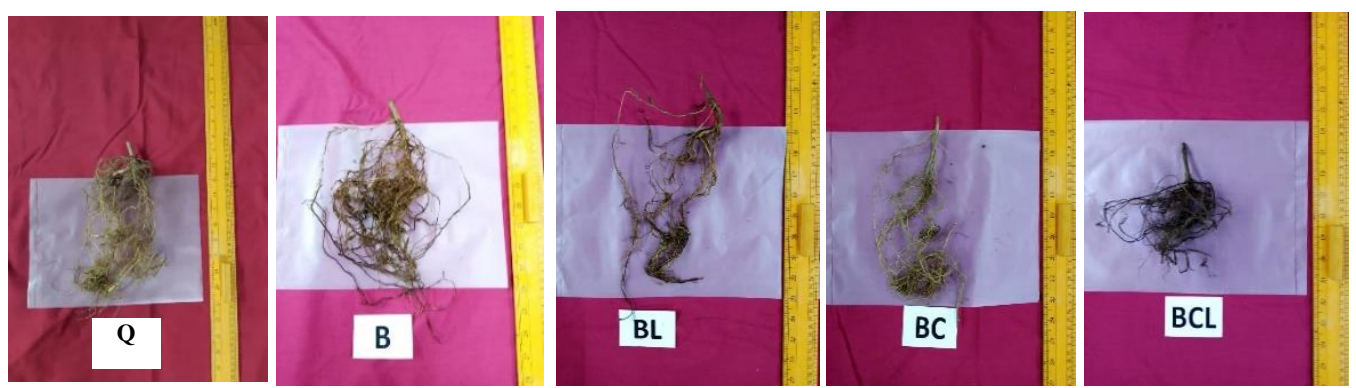

Figure 5. Photograph of roots of $M$. malabathricum on different treatments; $Q=$ control, $B=$ biochar, $B L=$ biochar + ground magnesium limestone, $B C=$ biochar + compost, $B C L=$ biochar + compost + ground magnesium limestone

Table 3. Pearson's correlation coefficient between physiological responses and root profiles of M. malabathricum

\begin{tabular}{|c|c|c|c|c|c|c|c|c|c|c|}
\hline \multirow[b]{2}{*}{ Parameters } & \multicolumn{6}{|c|}{ Physiological response } & \multicolumn{4}{|c|}{ Root profiles } \\
\hline & 짐 & 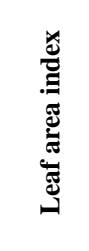 & 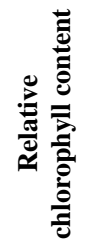 & 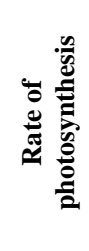 & 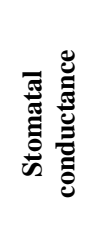 & 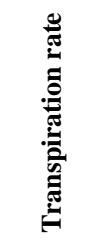 & 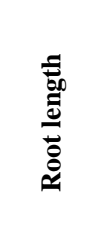 & 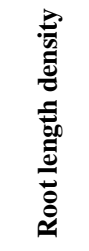 & 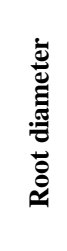 & 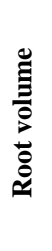 \\
\hline $\mathrm{pH}$ & 1 & & & & & & & & & \\
\hline Leaf area index & 0.187 & 1 & & & & & & & & \\
\hline Relative chlorophyll content & 0.374 & 0.083 & 1 & & & & & & & \\
\hline Rate of photosynthesis & $.654^{* *}$ & 0.332 & $.511^{* *}$ & 1 & & & & & & \\
\hline Stomatal conductance & -0.095 & $.416^{*}$ & $.444^{*}$ & $.511^{* *}$ & 1 & & & & & \\
\hline Transpiration rate & -0.105 & -0.235 & 0.260 & 0.261 & 0.231 & 1 & & & & \\
\hline Root length & -0.250 & -0.100 & $.764^{* *}$ & 0.352 & 0.354 & 0.298 & 1 & & & \\
\hline Root length density & -0.306 & 0.253 & $.742^{*}$ & 0.378 & 0.430 & 0.216 & $1.000^{* *}$ & 1 & & \\
\hline Root diameter & -0.219 & 0.311 & 0.197 & 0.018 & 0.074 & -0.209 & -0.108 & 0.237 & 1 & \\
\hline Root volume & -0.721 & $-.581^{*}$ & 0.133 & $-.628^{*}$ & -0.171 & -0.133 & 0.482 & 0.482 & $801^{*}$ & 1 \\
\hline
\end{tabular}

** Correlation is significant at the 0.01 level (2-tailed)

*Correlation is significant at the 0.05 level (2-tailed)

\section{Discussion}

\section{Soil pH and electrical conductivity}

The addition of biochar and ground magnesium limestone (BL) and the three combined amendments (BCL) had increased the soil $\mathrm{pH}$ prominently which was most probably attributed to the presence of ground magnesium limestone, a soil conditioner which was able to raise soil $\mathrm{pH}$ by alleviating the Al toxicity (Shamshuddin et al., 2016). However, liming alone was unable to alleviate Al toxicity entirely. Hence, organic matter such as biochar (B) was co-applied to effectively raise the soil $\mathrm{pH}$ 
(Gunarathne et al., 2017). The decomposition of organic matter leads to soil particle aggregation that provides good aeration and drainage (Kidd and Proctor, 2001), thus improving microbial activity and subsequently ameliorating soil acidity level. BLamended soil exhibited the lowest increment in the soil electrical conductivity (Fig. $1 b$ ) as higher soil $\mathrm{pH}$ indicated a lower amount of hydrogen ions. The findings by Aizat et al. (2014) had proven that the quantity of hydrogen ions influences the electrical conductivity of soil. Therefore, the high soil $\mathrm{pH}$ attributed to the low amount of hydrogen ions led to a low soil electrical conductivity (Atkinson et al., 2010; Martinsen et al., 2015; Qayyum et al., 2015).

\section{Leaf area index and relative chlorophyll content}

The leaf area index of $M$. malabathricum had increased with time throughout this study. The addition of biochar and compost (BC) had demonstrated the most prominent increase in leaf area index (Fig. 2a). This was likely caused by the co-application of biochar and compost which helped to improve the bioavailability of soil nutrients, as well as enhancement of the soil fertility which was proven by the higher leaf area index (Qayyum et al., 2015; Bolat and Öztürk, 2016). In addition, according to Rady et al. (2016), compost effectively increased the plant growth, which can be witnessed in the increased number of leaves and leaf area (Rady et al., 2016). Furthermore, regular irrigation during the growing period helps to increase the coverage of the leaf area (Yuan et al., 2012).

Chlorophyll content is one of the most vital biochemical indicators (Liu et al., 2014). According to Uysal (2018), the synthesis of chlorophyll relies on the presence of nutrients such as nitrogen and potassium (Uysal, 2018). It was evident from Figure $2 b$ that application of biochar resulted in minimum losses of chlorophyll content as compared to other treatments. The outcome from this research findings are consistent with those from Halim et al. (2018), who also reported a significance increase in relative chlorophyll content in plants treated with biochar. The lowest impact on the chlorophyll content of biochar applications may be linked to an increased soil $\mathrm{C}$ : $\mathrm{N}$ ratio in biochar, leading to the immobilization of soil $\mathrm{N}$ and hence the decreased plant uptake of $\mathrm{N}$ (Kammann et al., 2011). Next it may be attributed to $\mathrm{NH}_{4}{ }^{+}$adsorption on the biochar surface resulting in less $\mathrm{N}$ availability (Lehmann et al., 2002).

\section{Physiological responses}

Similar to soil $\mathrm{pH}, \mathrm{BL}$ treatment exhibited the highest photosynthetic rate in the final planting period (Table 1). This result implied that the higher soil $\mathrm{pH}$ would maximize the photosynthetic efficiency (Gentili et al., 2018). Moreover, Dighton (2014) had revealed that the soil $\mathrm{pH}$ would affect the accessibility and uptake of micro-nutrient such as magnesium that is implicated in the photosynthetic efficiency (Dighton and Krumins, 2014). The stomatal conductance and transpiration rates showed similar trends, where biochar (B) treatments showed the highest readings in the final planting period. This may be due to the ability of biochar to increase soil moisture content and improve soil water holding capacity (Simarani et al., 2018). Thus, the stomatal conductance and transpiration rate had increased with sufficient soil water available for plant growth (Yadav et al., 2019). Compared to the controls, the exogenous application of amendments increased the photosynthetic parameters in plants. The decline in photosynthetic characteristics of control (Q) plants could be caused by the 
contamination from heavy metal in chloroplast structures, which decreased the efficacy of photosynthetic activity systems (Rizwan et al., 2016a, b).

\section{Biomass}

Different treatments had responded differently in the development of dry matter (Table 2). Amongst the treatments, the application of biochar and compost (BC) yielded the highest leaf biomass. This result was in line with the leaf area index of the species studied where BC treatment recorded the highest leaf area index. This helped the photosynthetic active area to be enhanced with minimal biomass investment (Hikosaka et al., 2014). Furthermore, biomass was associated with the nutrient uptake as reported by Yadav et al. (2019). The co-application of biochar and compost was able to recover nutrients, resulting in the highest leaf biomass in this study (Oldfield et al., 2018). Biochar (B) treatment exhibited the highest stem biomass, which could possibly be due to its ability to increase plant-available phosphorus in soil and hence increased the plant growth (Gunarathne et al., 2017). Moreover, M. malabathricum grown with biochar and liming (BL) had demonstrated the highest root biomass after six months of planting. The use of the liming materials improved the soil $\mathrm{pH}$ as well as decreased the soil acidity, hydrogen and aluminum exchangeability (Onwuka et al., 2009). The current study found liming to have increased the root biomass due to soil $\mathrm{pH}$ increment, which was in accordance to the finding by Htwe et al. (2016). Furthermore, the use of compost and biochars alone or together in combination with fertilizer improved the chlorophyll content and a leaf biomass, which can also indicate an increased availability of macro and micronutrients (Mankasingh et al., 2011), producing vigorous plant growth and healthier plants, leading to increased vegetable biomass (Agegnehu et al., 2015). In addition the use of biochar as an amendment provides an ideal environment where the high nanoporosity and low density of the biochar improve the aeration and compost structure (Zhang et al., 2014). Besides, the large porosity and surface area enables sufficient microbial growth which increases the retention of plant nutrients through biochar application (Sanchez-Monedero et al., 2018).

\section{Root profiles}

M. malabathricum grown with biochar (B) showed the highest root length and root length density (Figs. 4a, 5b). The results indicated that the macro-nutrient such as calcium contained in biochar helped to enhance the root growth (Gunarathne et al., 2017). This was per the finding by Masto et al. (2013) in which the increased concentrations of several nutrients in plant tissues were witnessed in the application of biochar (Masto et al., 2013) Additionally, the bulk density in soils which indicates soil compaction can be decreased by applying biochar. Consequently, it increased the root penetration, allowing for higher uptake of nutrients from the soil solution (Lehmann and Joseph, 2015). This finding suggested a significant root to shoot ratio. It was likely that root growth had enhanced the shoot growth, which was evident from the highest stem biomass exhibited by biochar treatment. The presence of higher root length was arguably associated with higher chlorophyll content and concomitantly, higher stomatal conductance, and transpiration rate. Furthermore, Kumar et al. (2010) defined that one of the most promising characteristics for better physiological performance is the high values of root length (Kumar et al., 2010). 


\section{Correlations amongst the parameters studied}

A positive relationship between the soil $\mathrm{pH}$ and leaf area index (Table 3) indicated that soil fertility had improved with increased soil $\mathrm{pH}$ and hence, led to increased leaf area index. Mensah et al. (2018) and Kloss et al. (2013) reported that soil quality and soil fertility were improved with increasing soil pH (Mensah and Frimpong, 2018; Kloss et al., 2014). It is also interesting to observe that the soil $\mathrm{pH}$ is weakly negatively correlated with all root profile parameters. We may suggest that a decreased root length in high $\mathrm{pH}$ soils implies a reduced absorption of nutrients per root length. In unfavorable conditions, the fine roots need to be replaced more occasionally in order to retain its function (Godbold et al., 2003). Increased availability of nutrients under fertilization lessens the need for explorative growth in the fine root length and thus decreases the actual root length (Ostonen et al., 2007). The present findings seem to be consistent with other research, which found no variations in the common root range of the fine roots between 2.9 and $6.7 \mathrm{pH}$ gradients (Leuschner et al., 2004).

As observed in Table 3, the physiological response exhibited by the rate of photosynthesis was directly related to the relative chlorophyll content. Analysis of results revealed significantly positive correlation between the rate of photosynthesis against relative chlorophyll content with the $r$ value of 0.51 . The application of soil amendments to acidic soils could influence the absorption of nutrients (Saifuddin et al., 2016; Abideen et al., 2020; Simarani et al., 2018; Holland et al., 2018) which was crucial in the chlorophyll synthesis of leaves, therefore, contributes to a high rate of photosynthesis (Ainsworth and Rogers, 2007). In this study, a strong positive correlation was found between photosynthetic rate and stomatal conductance. This result indicated that the photosynthetic rate of the plant was stomatal-regulated, as reported by Jarvis and Davies (1998) that the increase in net photosynthesis was positively related to the increase in stomatal conductance. The use of biochar has been found to enhance the stomatal conductance (Solaiman et al., 2010) since higher stomatal behavior has shown that the plant can thrive under stressful conditions (Gindaba et al., 2005). Since M. malabathricum plants have been resilient towards soil acidification (Saifuddin et al., 2016; Maejima et al., 2017) the plant shows some potential effects when less soil moisture had occurred during the development of the plant (Caires et al., 2008). Water stress caused chloroplast envelop leaks (Kaiser et al., 1981), causes rapid response of stomatal conductance to reduce water status (Farquhar and Sharkey, 1982). The positive correlation observed between the transpiration rate and stomatal conductance indicated that soil water is sufficient whilst stomata open, allowing the transpiration process to take place (Ancu et al., 2014)

\section{Conclusions}

The finding of the present study indicate that the amendments of biochar alone exhibited the best performance on physiological responses and root profiles and can be recommended as a soil ameliorant under acidic soil condition for planting of $M$. malabathricum. Application of biochar leads to an increase in leaf area index, relative chlorophyll content, stomatal condition and transpiration rate. This finally contributes to an improvement of the plant nutrient uptake and plant water status. It also supports the increase of root length and root length density. Taken together, this study provides important insights that these factors can contribute to enhanced biomass production and water saving in $M$ Malabathricum grown on tropical acidic soil with low nutrient 
content. In addition, it might open the opportunity to sequester $\mathrm{CO}_{2}$. However, a detailed study is suggested in the near future to further examine the practical management of biochar such as timing of application towards growth of $M$. malabathricum.

Acknowledgements. This research was funded by the Ministry of Higher Education, Malaysia with reference code of FRGS/1/2018/WAB05/UM/01/1 (FRGS FP060-2018A) as well as Faculty Research Grant, Universiti Malaya (GPF005B-2018). The authors thank the University Malaya for experimental facilities.

\section{REFERENCES}

[1] Abdullah, R., Osman, N., Yusoff, S., Mohd Yusuf, H., Abdul Halim, N. S., Mohd Rosli, N. S. (2020): Effects of palm kernel biochar and food waste compost on the growth of palm lily (Cordyline fruticosa), coleus (Coleus sp.), and boat lily (Rhoeo discolor). Applied Ecology and Environmental Research 19: 205-218.

[2] Abideen, Z., Koyro, H.-W., Huchzermeyer, B., Bilquees, G., Khan, M. A. (2020): Impact of a biochar or a biochar-compost mixture on water relation, nutrient uptake and photosynthesis of Phragmites karka. - Pedosphere 30: 466-477.

[3] Agegnehu, G., Bird, M. I., Nelson, P. N., Bass, A. M. (2015): The ameliorating effects of biochar and compost on soil quality and plant growth on a Ferralsol. - Soil Research 53: $1-12$.

[4] Aimee, H., Normaniza, O. (2014): Physiological responses of Melastoma malabathricum at different slope orientations. - J. Trop. Plant Physiol 6: 10-22.

[5] Ainsworth, E. A., Rogers, A. (2007): The response of photosynthesis and stomatal conductance to rising [CO2]: mechanisms and environmental interactions. - Plant, cell \& Environment 30: 258-270.

[6] Aizat, A. M., Roslan, M., Sulaiman, W. N. A., Karam, D. S. (2014): The relationship between soil $\mathrm{pH}$ and selected soil properties in 48 years logged-over forest. International Journal of Environmental Sciences 4: 1129-1140.

[7] Ancu, S., Chitu, E., Marin, F. C., Ancu, I., Plopa, C. (2014): Correlation of stomatal conductance with photosynthetic capacity of six walnut cultivars from the national assortment. - South West J. Hortic. Biol. Environ 5: 1-10.

[8] Atkinson, C. J., Fitzgerald, J. D., Hipps, N. A. (2010): Potential mechanisms for achieving agricultural benefits from biochar application to temperate soils: a review. Plant and Soil 337: 1-18.

[9] Bezdicek, D., Beaver, T., Granatstein, D. (2003): Subsoil ridge tillage and lime effects on soil microbial activity, soil pH, erosion, and wheat and pea yield in the Pacific Northwest, USA. - Soil and Tillage Research 74: 55-63.

[10] Bin Wasli, M. E., Tanaka, S., Kendawang, J. J., Seman, L., Unang, B., Lat, J., Abdu, A., Morooka, Y., Sakurai, K. (2009): Vegetation conditions and soil fertility of fallow lands under intensified shifting cultivation systems in Sarawak, Malaysia. - Tropics 18: 115126.

[11] Bolat, I., Öztürk, M. (2016): Effects of altitudinal gradients on leaf area index, soil microbial biomass $\mathrm{C}$ and microbial activity in a temperate mixed forest ecosystem of Northwestern Turkey. - iForest-Biogeosciences and Forestry 10: 334.

[12] Caires, E., Garbuio, F., Churka, S., Barth, G., Corrêa, J. (2008): Effects of soil acidity amelioration by surface liming on no-till corn, soybean, and wheat root growth and yield. - European Journal of Agronomy 28: 57-64.

[13] Chen, D., Lan, Z., Bai, X., Grace, J. B., Bai, Y. (2013): Evidence that acidification-induced declines in plant diversity and productivity are mediated by changes 
in below-ground communities and soil properties in a semi-arid steppe. - Journal of Ecology 101: 1322-1334.

[14] Dai, H., Zhao, J., Ahmed, I. M., Cao, F., Chen, Z.-H., Zhang, G., Li, C., Wu, F. (2014): Differences in physiological features associated with aluminum tolerance in Tibetan wild and cultivated barleys. - Plant Physiology and Biochemistry 75: 36-44.

[15] Delhaize, E., Ryan, P. R. (1995): Aluminum toxicity and tolerance in plants. - Plant Physiology 107: 315 .

[16] Dighton, J., Krumins, J. A. (2014): Interactions in Soil: Promoting Plant Growth. Springer, Dordrecht.

[17] Dobermann, A., Fairhurst, T. (2000): Rice: Nutrient Disorders \& Nutrient Management. Int. Rice Res. Inst., Philippines.

[18] Farquhar, G. D., Sharkey, T. D. (1982): Stomatal conductance and photosynthesis. Annual Review of Plant Physiology 33: 317-345.

[19] Galvão, T. C. d. B., Pereira, A. R., Parizzi, M. G., Alves da Silva, H. (2010): Bioengineering techniques associated with soil nailing applied to slope stabilization and erosion control. - Natural Hazards Review 11: 43-48.

[20] Gentili, R., Ambrosini, R., Montagnani, C., Caronni, S., Citterio, S. (2018): Effect of soil $\mathrm{pH}$ on the growth, reproductive investment and pollen allergenicity of Ambrosia artemisiifolia L. - Frontiers in Plant Science 9: 1335.

[21] Gindaba, J., Rozanov, A., Negash, L. (2005): Photosynthetic gas exchange, growth and biomass allocation of two Eucalyptus and three indigenous tree species of Ethiopia under moisture deficit. - Forest Ecology and Management 205: 127-138.

[22] Godbold, D. L., Fritz, H.-W., Jentschke, G., Meesenburg, H., Rademacher, P. (2003): Root turnover and root necromass accumulation of Norway spruce (Picea abies) are affected by soil acidity. - Tree Physiology 23: 915-921.

[23] Graham, M., Haynes, R. (2005): Organic matter accumulation and fertilizer-induced acidification interact to affect soil microbial and enzyme activity on a long-term sugarcane management experiment. - Biology and Fertility of Soils 41: 249-256.

[24] Gunarathne, V., Mayakaduwa, S., Vithanage, M. (2017): Biochar's influence as a soil amendment for essential plant nutrient uptake. - Essential Plant Nutrients. Springer.

[25] Halim, A., Sa'adah, N., Abdullah, R., Karsani, S. A., Osman, N., Panhwar, Q. A., Ishak, C. F. (2018): Influence of soil amendments on the growth and yield of rice in acidic soil. - Agronomy 8: 165.

[26] Hikosaka, K., Yasumura, Y., Muller, O., Oguchi, R. (2014): Resource Allocation and Trade-offs in Carbon Gain of Leaves under Changing Environment. - In: Tausz, M., Grulke, N. (eds.) Trees in a Changing Environment. Springer, Dordrecht.

[27] Hoegberg, P., Fan, H., Quist, M., Binkley, D., Tamm, C. O. (2006): Tree growth and soil acidification in response to 30 years of experimental nitrogen loading on boreal forest. Global Change Biology 12: 489-499.

[28] Holland, J. E., Bennett, A. E., Newton, A. C., White, P. J., McKenzie, B. M., George, T. S., Pakeman, R. J., Bailey, J. S., Fornara, D. A., Hayes, R. C. (2018): Liming impacts on soils, crops and biodiversity in the UK: a review. - Science of the Total Environment 610-611: 316-332.

[29] Htwe, W. M., Kyawt, Y. Y., Thaikua, S., Imai, Y., Mizumachi, S., Kawamoto, Y. (2016): Effects of liming on dry biomass, lead concentration and accumulated amounts in roots and shoots of three tropical pasture grasses from lead contaminated acidic soils. Grassland Science 62: 257-261.

[30] Jarvis, A. J., Davies, W. J. (1998): The coupled response of stomatal conductance to photosynthesis and transpiration. - Journal of Experimental Botany 49: 399-406.

[31] Jien, S.-H., Wang, C.-S. (2013): Effects of biochar on soil properties and erosion potential in a highly weathered soil. - Catena 110: 225-233.

[32] Kaiser, W. M., Stepper, W., Urbach, W. (1981): Photosynthesis of isolated chloroplasts and protoplasts under osmotic stress. - Planta 151: 375-380. 
[33] Kammann, C. I., Linsel, S., Gößling, J. W., Koyro, H.-W. (2011): Influence of biochar on drought tolerance of Chenopodium quinoa Willd and on soil-plant relations. - Plant and Soil 345: 195-210.

[34] Kawaletz, H., Mölder, I., Annighöfer, P., Terwei, A., Zerbe, S., \& Ammer, C. (2014): Pot experiments with woody species - a review. - Forestry: An International Journal of Forest Research 87(4): 482-491.

[35] Kidd, P. S., Proctor, J. (2001): Why plants grow poorly on very acid soils: are ecologists missing the obvious? - Journal of Experimental Botany 52: 791-799.

[36] Kloss, S., Zehetner, F., Wimmer, B., Buecker, J., Rempt, F., Soja, G. (2014): Biochar application to temperate soils: effects on soil fertility and crop growth under greenhouse conditions. - Journal of Plant Nutrition and Soil Science 177: 3-15.

[37] Kochian, L. V., Pineros, M. A., Hoekenga, O. A. (2005): The Physiology, Genetics and Molecular Biology of Plant Aluminum Resistance and Toxicity. - In: Lambers H., Colmer T. D. (eds.) Root Physiology: From Gene to Function. Springer, Dordrecht.

[38] Kong, S.-H., Loh, S. K., Bachmann, R. T., Zainal, H., Cheong, K. Y. (2019): Palm kernel shell biochar production, characteristics and carbon sequestration potential. - Journal of Oil Palm Research 31: 508-520.

[39] Kumar, N., Nandwal, A., Devi, S., Sharma, K., Yadav, A., Waldia, R. (2010): Root characteristics, plant water status and $\mathrm{CO} 2$ exchange in relation to drought tolerance in chickpea. - Journal of SAT Agricultural Research 8: 1-5.

[40] Lehmann, J., Joseph, S. (2015): Biochar for Environmental Management: Science, Technology and Implementation. - Routledge, Abingdon.

[41] Lehmann, J., da Silva Jr, J. P., Rondon, M., Cravo, M. d. S., Greenwood, J., Nehls, T., Steiner, C., Glaser, B. (2002): Slash-and-char - a feasible alternative for soil fertility management in the central Amazon. - Proceedings of the 17th World Congress of Soil Science 2002. Soil and Fert. Soc. of Thailand, Bangkok, pp. 1-12.

[42] Leuschner, C., Hertel, D., Schmid, I., Koch, O., Muhs, A., Hölscher, D. (2004): Stand fine root biomass and fine root morphology in old-growth beech forests as a function of precipitation and soil fertility. - Plant and Soil 258: 43-56.

[43] Liu, B., Yue, Y.-M., Li, R., Shen, W.-J., Wang, K.-L. (2014): Plant leaf chlorophyll content retrieval based on a field imaging spectroscopy system. - Sensors 14: 1991019925.

[44] Maejima, E., Osaki, M., Wagatsuma, T., Watanabe, T. (2017): Contribution of constitutive characteristics of lipids and phenolics in roots of tree species in Myrtales to aluminum tolerance. - Physiologia Plantarum 160: 11-20.

[45] Mankasingh, U., Choi, P.-C., Ragnarsdottir, V. (2011): Biochar application in a tropical, agricultural region: A plot scale study in Tamil Nadu, India. - Applied Geochemistry 26: S218-S221.

[46] Martinsen, V., Alling, V., Nurida, N., Mulder, J., Hale, S., Ritz, C., Rutherford, D., Heikens, A., Breedveld, G. D., Cornelissen, G. (2015): pH effects of the addition of three biochars to acidic Indonesian mineral soils. - Soil Science and Plant Nutrition 61: 821834.

[47] Masto, R. E., Kumar, S., Rout, T., Sarkar, P., George, J., Ram, L. (2013): Biochar from water hyacinth (Eichornia crassipes) and its impact on soil biological activity. - Catena 111: 64-71.

[48] Mensah, A. K., Frimpong, K. A. (2018): Biochar and/or compost applications improve soil properties, growth, and yield of maize grown in acidic rainforest and coastal savannah soils in Ghana. - International Journal of Agronomy 2018.

[49] Mullen, R., Lentz, E., Watson, M. (2007): Soil Acidity and Liming for Agronomic Production. - Ohio State University Extension Fact Sheet AGF 505-07.

[50] Oldfield, T. L., Sikirica, N., Mondini, C., López, G., Kuikman, P. J., Holden, N. M. (2018): Biochar, compost and biochar-compost blend as options to recover nutrients and sequester carbon. - Journal of Environmental Management 218: 465-476. 
[51] Onwuka, M., Osodeke, V., Ano, A. (2009): Use of liming materials to reduce soil acidity and affect maize (Zea mays L) growth parameters in Umudike, Southeast Nigeria. - Pat 5: 386-396.

[52] Osman, N., Barakbah, S. S. (2011): The effect of plant succession on slope stability. Ecological Engineering 37: 139-147.

[53] Osman, N., Saifuddin, M., Halim, A. (2014): Contribution of Vegetation to Alleviate Slope's Erosion and Acidity. - In: Hernandez Soriano, M. C. (ed.) Environmental Risk Assessment of Soil Contamination. InTech, London.

[54] Ostonen, I., Püttsepp, Ü., Biel, C., Alberton, O., Bakker, M., Lõhmus, K., Majdi, H., Metcalfe, D., Olsthoorn, A., Pronk, A. (2007): Specific root length as an indicator of environmental change. - Plant Biosystems 141: 426-442.

[55] Piñuela, Y. G., Alday, J., Oliach, D., Bolaño, F., Colinas, C., Bonet, J. A. (2020): Use of inoculator bacteria to promote Tuber melanosporum root colonization and growth on Quercus faginea saplings. - Forests 11(8): 792.

[56] Qayyum, M. F., Ashraf, I., Abid, M., Steffens, D. (2015): Effect of biochar, lime, and compost application on phosphorus adsorption in a Ferralsol. - Journal of Plant Nutrition and Soil Science 178: 576-581.

[57] Rady, M. M., Semida, W. M., Hemida, K. A., Abdelhamid, M. T. (2016): The effect of compost on growth and yield of Phaseolus vulgaris plants grown under saline soil. International Journal of Recycling of Organic Waste in Agriculture 5: 311-321.

[58] Rahman, M., Lee, S.-H., Ji, H. C., Kabir, A. H., Jones, C. S., Lee, K.-W. (2018): Importance of mineral nutrition for mitigating aluminum toxicity in plants on acidic soils: current status and opportunities. - International Journal of Molecular Sciences 19: 3073.

[59] Rizwan, M., Ali, S., Abbas, T., Zia-ur-Rehman, M., Hannan, F., Keller, C., Al-Wabel, M. I., Ok, Y. S. (2016a). Cadmium minimization in wheat: a critical review. - Ecotoxicology and Environmental Safety 130: 43-53.

[60] Rizwan, M., Ali, S., Adrees, M., Rizvi, H., Zia-ur-Rehman, M., Hannan, F., Qayyum, M. F., Hafeez, F., Ok, Y. S. (2016b). Cadmium stress in rice: toxic effects, tolerance mechanisms, and management: a critical review. - Environmental Science and Pollution Research 23: 17859-17879.

[61] Saifuddin, M., Normaniza, O. (2016): Rooting characteristics of some tropical plants for slope protection. - Journal of Tropical Forest Science 28(4): 469-478.

[62] Saifuddin, M., Osman, N., Idris, R. M., Halim, A. (2016): The effects of pre-aluminum treatment on morphology and physiology of potential acidic slope plants. - Kuwait Journal of Science 43.

[63] Salleh, N., Ishak, C., Saat, A., Yong, S. (2017): Aluminum toxicity in acid sulfate soil alleviated with biogenic liming composites of blood cockle shell and palm kernel shell. Journal of Fundamental and Applied Sciences 9: 965-980.

[64] Sanchez-Monedero, M., Cayuela, M., Roig, A., Jindo, K., Mondini, C., Bolan, N. (2018): Role of biochar as an additive in organic waste composting. - Bioresource Technology 247: 1155-1164.

[65] Shamshuddin, J. (2006): Acid Sulfate Soils in Malaysia. - Universiti Putra Malaysia Press, Serdang, Selangor.

[66] Shamshuddin, J., Fauziah, C., Anda, M., Kapok, J., Shazana, M. (2011): Using ground basalt and/or organic fertilizer to enhance productivity of acid soils in Malaysia for crop production. - Malaysian Journal of Soil Science 15: 127-146.

[67] Shamshuddin, J., Panhwar, Q., Shazana, M., Elisa, A., Fauziah, C., Naher, U. (2016): Improving the productivity of acid sulfate soils for rice cultivation using limestone, basalt, organic fertilizer and/or their combinations. - Sains Malaysiana 45: 383-392.

[68] Simarani, K., Azlan Halmi, M. F., Abdullah, R. (2018): Short-term effects of biochar amendment on soil microbial community in humid tropics. - Archives of Agronomy and Soil Science 64: 1847-1860. 
[69] Solaiman, Z. M., Sarcheshmehpour, M., Abbott, L. K., Blackwell, P. (2010): Effect of biochar on arbuscular mycorrhizal colonisation, growth, $\mathrm{P}$ nutrition and leaf gas exchange of wheat and clover influenced by different water regimes. - Proceedings of the 19th World Congress of Soil Science: Soil Solutions for a Changing World, Brisbane, Australia, 1-6 August 2010. Symposium 2.3.1 The Soil-Root Interface.

[70] Soriano, M. C. H. (2014): Environmental Risk Assessment of Soil Contamination. - BoD - Books on Demand, Norderstedt.

[71] Uysal, E. (2018): Effects of nitrogen fertilization on the chlorophyll content of apple. Meyve Bilimi 5: 12-17.

[72] Van den Berg, L. J., Vergeer, P., Rich, T. C., Smart, S. M., Guest, D., Ashmore, M. R. (2011): Direct and indirect effects of nitrogen deposition on species composition change in calcareous grasslands. - Global Change Biology 17: 1871-1883.

[73] Watanabe, T., Jansen, S., Osaki, M. (2006): Al-Fe interactions and growth enhancement in Melastoma malabathricum and Miscanthus sinensis dominating acid sulphate soils. Plant, Cell \& Environment 29: 2124-2132.

[74] Yadav, V., Karak, T., Singh, S., Singh, A. K., Khare, P. (2019): Benefits of biochar over other organic amendments: responses for plant productivity (Pelargonium graveolens L.) and nitrogen and phosphorus losses. - Industrial Crops and Products 131: 96-105.

[75] Yuan, Y., Chen, D., Shao, X., Li, Y., Ding, F., Kwizera, C. (2012): Effects of different irrigation quantities on plant growth and photosynthesis characters of flue-cured tobacco. - Journal of Food, Agriculture \& Environment 10: 1160-1163.

[76] Zhang, J., Lü, F., Luo, C., Shao, L., He, P. (2014): Humification characterization of biochar and its potential as a composting amendment. - Journal of Environmental Sciences 26: 390-397. 